Article

\title{
Climate Change: Implications for the Assumptions, Goals and Methods of Urban Environmental Planning
}

\author{
Kristina Hill \\ College of Environmental Design, University of California Berkeley, Berkeley, CA 94720, USA; E-Mail: kzhill@berkeley.edu
}

Submitted: 14 September 2016| Accepted: 12 December 2016 | Published: 29 December 2016

\begin{abstract}
As a result of increasing awareness of the implications of global climate change, shifts are becoming necessary and apparent in the assumptions, concepts, goals and methods of urban environmental planning. This review will present the argument that these changes represent a genuine paradigm shift in urban environmental planning. Reflection and action to develop this paradigm shift is critical now and in the next decades, because environmental planning for cities will only become more urgent as we enter a new climate period. The concepts, methods and assumptions that urban environmental planners have relied on in previous decades to protect people, ecosystems and physical structures are inadequate if they do not explicitly account for a rapidly changing regional climate context, specifically from a hydrological and ecological perspective. The over-arching concept of spatial suitability that guided planning in most of the $20^{\text {th }}$ century has already given way to concepts that address sustainability, recognizing the importance of temporality. Quite rapidly, the concept of sustainability has been replaced in many planning contexts by the priority of establishing resilience in the face of extreme disturbance events. Now even this concept of resilience is being incorporated into a novel concept of urban planning as a process of adaptation to permanent, incremental environmental changes. This adaptation concept recognizes the necessity for continued resilience to extreme events, while acknowledging that permanent changes are also occurring as a result of trends that have a clear direction over time, such as rising sea levels. Similarly, the methods of urban environmental planning have relied on statistical data about hydrological and ecological systems that will not adequately describe these systems under a new climate regime. These methods are beginning to be replaced by methods that make use of early warning systems for regime shifts, and process-based quantitative models of regional system behavior that may soon be used to determine acceptable land uses. Finally, the philosophical assumptions that underlie urban environmental planning are changing to address new epistemological, ontological and ethical assumptions that support new methods and goals. The inability to use the past as a guide to the future, new prioritizations of values for adaptation, and renewed efforts to focus on intergenerational justice are provided as examples. In order to represent a genuine paradigm shift, this review argues that changes must begin to be evident across the underlying assumptions, conceptual frameworks, and methods of urban environmental planning, and be attributable to the same root cause. The examples presented here represent the early stages of a change in the overall paradigm of the discipline.
\end{abstract}

\section{Keywords}

climate change; ecological planning; planning theory; sea level rise; urban environments

\section{Issue}

This article is part of the issue "Paradigm Shifts in Urban Planning", edited by Matthias Drilling (University of Applied Sciences and Arts Northwestern Switzerland, Switzerland), Efrat Eizenberg (Israel Institute of Technology, Israel), Janet Stanley (University of Melbourne, Australia), Lee Boon Thong (Nilai University, Malaysia) and Andreas Wesener (Lincoln University Canterbury, New Zealand).

(C) 2016 by the author; licensee Cogitatio (Lisbon, Portugal). This article is licensed under a Creative Commons Attribution 4.0 International License (CC BY).

\section{Introduction}

Anthropogenic climate change is already causing measurable effects in regional and local environments (Boon
\& Mitchell, 2015; DeConto \& Pollard, 2016; Hannaford, 2015; Kelley, Mohtadi, Cane, Seager, \& Kushnir, 2015). There is increasing evidence that these changes are forcing urban environmental planners to gradually alter their 
epistemological assumptions, conceptual frameworks, goals, and methods. A paradigm shift in an applied discipline such as planning involves precisely these types of changes, in everything from philosophical assumptions to applied methods. This paper will use examples to argue that the phenomenon of entering a new climate era is producing a paradigm shift in urban environmental planning. However, like climate change itself, this shift is still in its early stages.

In this review, I argue that the goals and concepts, methods, and philosophical underpinnings of urban environmental planning are beginning to shift. A broad literature of examples is available, many of which have emerged from the demands of current practice rather than from a theoretical position. An emerging literature proposes new frameworks and methods for urban planning generally to respond to the implications of climate change (Hodson \& Marvin, 2009; Jabareen, 2015; Stone, 2012). Like these authors, I contend that the implications of climate change require us to shift some of the fundamental assumptions of planning. However, while they address more general planning practices, I will focus specifically on theories and plans that address the biophysical conditions of the city and its region. I intend for this review to serve as an original contribution by categorizing and synthesizing emerging patterns in theory and practice. Its focus on examples from North American cases and literature in urban environmental planning allows my claim of an emerging paradigm shift to remain grounded in a network of academics and practitioners who are aware of and influenced by each other's work. Throughout, I will argue that a coherent paradigm shift can only be said to exist if changes are occurring simultaneously in the key assumptions, conceptual frameworks, and methods of a discipline, and that these changes must be driven by the same root cause.

\section{Urban Environmental Planning and Biodiversity: The U.S. Context}

My observations of a paradigm shift in environmental planning are rooted in novel planning efforts over the last fifteen years that were intended to protect biodiversity from urbanization, as well as planning efforts that originate in a desire to establish resilience to flooding events, or-more recently-to adapt to permanent trends such as rising sea levels. For that reason, it is important to briefly note two key U.S. Federal laws, the expansion and enforcement of which led U.S. urban environmental planning to change under different conditions and with different timing than in Europe and Asia.

Since the late 1960s, urban environmental planning in western North America has paid increasing attention to biodiversity (Thomas, 2003). Like South America, Australia, India and Africa, western North America was industrialized relatively late, developing cities in the modern sense only after 1850 (Otterstrom, 2004). Large wild animals with strong cultural associations continue to exist within many urban ecosystems-not just in rural areas. Cities across the North American west include small but visible populations of mountain lions (Puma concolor), black bears (Ursus americanus), bald eagles (Haliaeetus leucocephalus), and Chinook salmon (Oncorhynchus tshawytscha), among other species (Beatley, 2000). The US Endangered Species Act (ESA) of 1973 was initially focused on conserving populations of species, rather than on maintaining a network of protected habitats, as in the European Union's Natura 2000 legislation (Verschuuren, 2004). Large animals with extensive ranges often pass through urban and suburban areas during migrations or in search of resources, and the US Endangered Species Act protects these species even from the indirect effects of urbanization, such as pollution in stormwater runoff. For these reasons, urban environmental planning in the United States, particularly the western U.S., has been challenged to plan and design urban areas to accommodate large wildlife species whose populations are in decline, such as the Chinook salmon (Simenstad, Tanner, Crandell, White, \& Cordell, 2005), which was listed as threatened under Federal law in the Puget Sound region of Washington State in 1999 (National Oceanic and Atmospheric Administration, 1999).

Similarly, the U.S. Clean Water Act of 1972 now strictly regulates pollution loads in urban stormwater runoff that originate in dispersed, non-point sources such as motorized vehicle traffic (Craig, 2005). Cities must not exceed established maximum loads, or they face penalties. This extension of the Clean Water Act to set standards for urban runoff prompted widespread experimentation with landscape-based methods for detaining runoff and filtering pollutants, significantly expanding the technical role of urban environmental planners. Together, these two Federal laws led to significant changes in urban infrastructure design and urban environmental planning since the 1990s, particularly in regions that discharge urban runoff to ecosystems with high biodiversity, such as the Puget Sound in the Pacific Northwest (Feist, Buhle, Arnold, Davis, \& Scholz, 2011; Simenstad et al., 2005), and the Chesapeake Bay in the mid-Atlantic region.

It would be impossible to describe the recent trend towards a paradigm shift in North American urban environmental planning without noting these regulations. The efforts of urban planners to optimize the pattern and performance of cities to support aquatic habitat and higher levels of water quality are important points of origin for the paradigm shifts we confront today in relation to climate change (Ward, Anderson, Beechie, Pess, \& Ford, 2015).

In the first section of this paper, I will present changes in the conceptual frameworks of urban environmental planning as a result of extreme weather events and climate trends. The second section of this paper will contain a review of key methods that are changing as a result of the same phenomena. The third and final section will suggest changes that are beginning to occur in the philo- 
sophical assumptions that underlie urban environmental planning, which I argue is the final component necessary to identify a coherent paradigm shift.

\section{Changing Concepts: From "Suitability" to "Sustainable Development" to "Resilience" to "Adaptation"}

Over the last thirty years, the stated goals and associated conceptual frameworks of urban environmental planning in the U.S. have changed, and these changes have occurred with increasing speed. Before the 1980s, the dominant framework was driven by the search for "suitability," defined as a good match between the physical characteristics of a location and its land use, or the type of design that is used (Hills, 1974; McHarg, 1969; Steinitz, 1990). Since that time, the broad goal of urban environmental planning has shifted to an effort to manage "sustainable development" (World Commission on Environment and Development, 1987), which recognized that there are limits to development that involve temporal patterns of resource use and availability, as well as spatial patterns. More recently, the goal of many cities and regions has been to achieve "resilience," or, an ability to recover quickly from disasters such as earthquakes, hurricanes, river flooding, fires, and terrorist attacks (Chelleri, Waters, Olazabal, \& Minucci, 2015). Barely a decade old, the concept of "resilience" to temporary events has already begun to be subsumed under the need to engage in permanent adaptation to climate trends. The concept of "adaptation" refers to reducing the vulnerability of an area to permanent, incremental trends such as higher sea levels, reduced regional rainfall or snowfall, new geographic patterns of disease transmission as a result of warming winters, and extended heat waves-along with the secondary and tertiary effects of these trends on urban regions (Hill, 2015).

These changes in the rationales and concepts of planning represent underlying changes in our understanding of the complexity of inter-related environmental patterns in space and time. They also represent shifts in the goals and rationales for planning. Ian McHarg's lectures and writing in the 1970s strongly emphasized the need to restrict negative human impacts on the environment (see for example his lecture titled, Man, Planetary Disease, [McHarg, 1971]). In contrast, the Brundtland Report emphasized the potential for human cities and expanding resource uses to be successfully integrated into the natural systems of the planet (World Commission on Environment and Development, 1987). Shortly after, symposia were held that recognized global climate trends as a challenge to sustainable resource use, although optimism was still high that global climate change could be avoided through careful planning (DeFries \& Malone, 1989).

Since the late 1980s, the concept of sustainable development has been used widely in urban environmental planning (Wheeler \& Beatley, 2014). In North Amer- ica, it has often been applied by adopting the goal of sustaining pre-development processes (particularly hydrological flow regimes and species movement patterns) and the biodiversity that is characteristic of a geographic region (Bixler et al., 2016). This overall goal of sustaining pre-development processes and biodiversity led to the development of a set of concepts and methods within the patchwork of local land-use and infrastructure authorities that limit the scope of U.S. urban planning. Together, the goal itself and the concepts and methods associated with it might be called the "sustainable development conceptual framework" in American urban environmental planning.

As it developed in the U. S., sustainable development relied on the ability of planners and ecologists to describe historical ecological relationships, inferred from soil patterns and other markers of past processes, and track the effects of contemporary resource uses on the health of those historical relationships (Kerans \& Karr, 1994; Rapport et al., 1998). Similarly, the concept of a "native species" in North America relies on a determination that a species has been present in a region over thousands of years, and implies an assumption of relative stability in species distributions (Goodenough, 2010). The concept of "native" is fundamentally historical and ignores the scientific knowledge that species have moved as climates have changed throughout the Holocene. The concept doesn't consider whether or not a species is well suited to a particular region as its climate changes. This makes the central concept of "native species" vulnerable to becoming completely outdated in the next few decades (Baker et al., 2013; Sorte, 2013). It also points out limitations in the way that the concept of sustainable development has been applied in U.S. urban environments, because of its conceptual dependency on the idea of sustaining pre-development processes (Hobbs et al., 2014; Palmer \& Ruhl, 2015). The concepts of a "reference condition" and a "native species" both need significant re-consideration, along with the assumption that the scale of processes that underlie both biodiversity patterns and cultural landscapes, such as hydrologic flows, will continue to resemble the patterns of the last 1,000-3,000 years (Rockström et al., 2014). To the extent that the concept of sustainable development in North American urban regions became synonymous with the goals of sustaining native species and pre-development hydrologic processes, the concept is not robust in an era of rapid climate change.

The newer term that has already replaced "sustainable development" as a goal and framework in North American cities, particularly coastal cities, is "resilience" (Coaffee \& Lee, 2016). This goal refers to the ability of a system to recover its functions quickly after a major disturbance. The very frequent use of this term in the last decade reflects a heightened awareness of the potential for extreme weather to produce destructive events in North American cities. Hurricane Katrina in New Orleans (2005) and Superstorm Sandy in the New York region 
(2012) were important events that drove the adoption of resilience as the highest-priority goal of these coastal cities (Weisz, Blumberg, \& Keenan, 2015).

In post-hurricane New Orleans, a series of workshops sponsored by the Dutch Embassy brought Dutch engineers and urban planners to the U.S., working alongside American planners and engineers (Waggonner \& Meyer, 2010). These workshops eventually led to the development of a new water management strategy for the New Orleans region (Waggonner and Ball Architects, 2013) which emphasizes strategies for managing stormwater runoff from an extreme rainfall event. In New York, federal agencies sponsored a design/planning competition called "Rebuild by Design" that emphasized strategies for that region to recover from the types of storm surges and extreme rainfall related to large hurricane events (Hurricane Sandy Rebuilding Task Force, 2013). "Resilience" was used frequently to describe the desired capacity to recover more quickly from a disastrous event.

Yet it is important to note that the shift in goals and framework from "sustainable development" to "resilience" occurred because of a focus on disastrous single events, not on the incremental trends (such as higher sea levels) that are expected as a result of climate change (Shi, Chu, \& Debats, 2015). Initially, the use of the term "resilience" could be seen as an extension of the sustainable development framework, because it marks planners' recognition that sustaining cities requires that those cities must be prepared for major disaster eventsfrom hurricanes to terrorist attacks. But as media news sources, academics and professional planners in some regions of the United States have converged on a general level of acceptance that climate change is happening, the term "sustainable" has frequently been replaced by the term "resilience" as public agencies present their planning goals. This represents a significant shift, and often implies an unstated recognition that some of the land and infrastructure cities administer today may not be sustained into the future (Wang, Tang, \& Wang, 2014). The poignancy of this reality is palpable in urban neighborhoods that are unlikely to ever fully recover from an extreme storm, such as the still largely depopulated Lower Ninth Ward of New Orleans (Landphair, 2007).

Even more recently, a framework is emerging that recognizes the goal of incremental, permanent environmental change in urban planning. This became evident in 2009, when one of the leading public agencies of the San Francisco Bay area sponsored a design competition called "Rising Tides" (King, 2009). In this competition, the San Francisco Bay Conservation and Development Commission (BCDC) called for urban and environmental planning strategies to address the permanent sea level rise associated with climate change. The competition was followed by a planning program that is working county-by-county to identify needs for adaptation in public infrastructure, called "Adapting to Rising Tides" (http://www.adaptingtorisingtides.org). The concept of using adaptation to adjust to permanent changes while building in resilience to extreme events is now embedded in planning conversations in the San Francisco Bay Area. In other parts of the U.S., political affiliation seems to affect the perceived need for adaptation in addition to resilience (Botzen, Michel-Kerjan, Kunreuther, de Moel, \& Aerts, 2016). Terms like "recurrent flooding" are used instead of referring to adaptation to sea level rise in regions where climate change is not an acknowledged phenomenon (Huler, 2012). But this is a special case of language being limited by regional politics, not by the knowledge or goals of the planning discipline.

My argument that a paradigm shift is occurring in urban environmental planning relies on the conclusion that these changes in terminology for goals and conceptual frames are more than just semantic. The change from "sustainability" to "resilience" to "adaptability" reflects changes in the underlying goals of urban environmental planning, driven by a growing comprehension of the types of significant changes cities are experiencing. Pursuing the goal of "resilience" operates as a kind of halfstep between the paradigms of sustainability and adaptation, since resilience to extreme events will be needed in the future as much as it is needed today. In that sense, the change in conceptual frames is really a change from the "sustainability framework" to the "adaptation framework," while retaining the goal of resilience (meaning, the ability to recovery quickly from a disaster event) into the new climate future.

\section{Changes in Methods for Urban Environmental Planning}

If a paradigm shift is indeed occurring in urban environmental planning in response to our awareness of global climate change, this shift should be evident in the methods of planning as well as in its goals and conceptual frameworks. In fact, some methods are changing. This is evident in several areas of planning work, from physical and social vulnerability assessments to typological design methods and statistically-based methods of sizing systems for flood protection. This section will present examples of these methodological changes.

The first area of methods that are changing might be referred to broadly as vulnerability assessments (Füssel \& Klein, 2006). Many communities in the United States are engaged in what is currently a somewhat chaotic effort to define the appropriate scope and analytical methods for vulnerability studies (Berke et al., 2015), sometimes assisted by guidance from state and county jurisdictions (see for example, California Coastal Commission, 2015). These may be studies of vulnerability to physical phenomena such as sea level rise and freshwater flooding, earthquake liquefaction, fire, or drought, as well as new public health hazards or social inequality drivers. Terms such as exposure, risk, vulnerability, and hazard are not standardized, nor are the timeframes that should be used in order for the assessments to reflect future conditions. Generally, only primary exposures are stud- 
ied, which excludes the study of secondary network impacts such as traffic congestion caused by fire or flooding effects on roadways (Biging, Radke, \& Lee, 2012). Potential changes in ecological conditions that might be considered tertiary exposures are also rarely considered in vulnerability plans, such as harmful algal blooms driven by nutrient inputs and warming temperatures that affect the use and value of coastal property, along with human health (Glibert et al., 2014).

Moreover, there are new questions about the methods that are appropriate for assessing social vulnerability in vulnerability plans. The index of social vulnerability was developed in relation to events, not long-term permanent adaptation processes (Cutter, Boruff, \& Shirley, 2003). This index includes variables such as income, family size, languages spoken, and race, which have been correlated with vulnerability in emergency events in the US southeast. But the current need is for methods that will allow us to predict the ability of different adaptation proposals to increase social equity, rather than maintain the status quo. The term "vulnerable" itself is becoming contested in new ways, as communities that are relatively wealthy but physically vulnerable use the term to justify new funding that could help them adapt to changes such as sea level rise (see for example the vulnerability study for affluent coastal communities that serve as vacation rental properties most of each year, in Marin, CaliforniaMarin County Community Development Agency, 2015).

The second category of changing methods is the statistical methods that are deeply embedded in the epistemological assumptions of environmental planning and risk management, such as calculating the statistical recurrence interval of rainfall, flood or fire events. These methods rely on the concept of stationarity, which assumes that variability in natural systems occurs within a consistent envelope or range of values over long periods of time. As one author in the recent method debates has noted, "In view of the magnitude and ubiquity of the hydroclimatic change apparently now under way, however, we assert that stationarity is dead and should no longer serve as a central, default assumption in waterresource risk assessment and planning. Finding a suitable successor is crucial for human adaptation to changing climate," (Milly et al., 2008). While there is currently an active debate about what methods can be used to compensate for climate change, it is clear that methods will need to change, particularly as the statistical signal of climate change becomes stronger (Milly et al., 2015; Stedinger \& Griffis, 2011; Stroup, 2011). If stationarity is "dead," the loss of its associated methodological assumptions represents a very significant shift from past methods in urban environmental planning as well as ecosystem management, water resources and civil engineering.

The third area of change is in the development of socalled "early warning systems." New methods are emerging that attempt to track the statistical dynamics of system behavior in order to identify and eventually to predict abrupt changes in state. Some researchers are look- ing for so-called regime shifts using moving-window calculations as an analytical tool with large datasets, tracking the range of variability in those data over time, among other variables (Dakos, Carpenter, van Nes, \& Scheffer, 2014). These new methods are being used to forecast changes in the ecosystem or population-level status of conditions in lakes, wetlands, housing markets, and human biomedical assays associated with epileptic seizures. The difficulty is in identifying the right variables to track, according to some authors (Pace, Carpenter, \& Cole, 2015). The intention of these new methods is to allow managers and planners to make adjustments in systems before they shift to a less-desirable state, as in a lake that becomes eutrophic or filled with toxic algae, or a tidal wetland that collapses to a mudflat because of repeated storm surge events. One of the most interesting theoretical observations that has come out of these new methods with respect to urban environmental planning is the observation that habitat connectivity may be less desirable in a changing climate (Scheffer et al., 2012). Redundancy may preserve more biodiversity under conditions of stress than connectivity. This research on regime shifts is in early stages as it relates to urban planning, but it is likely to generate a suite of new methods associated with the adaptation framework in planning.

Fourth, there is also a need for generative methods that help planners identify appropriate spatial strategies for coastal protection and urban district design. It seems likely that new typologies will be needed that serve to organize the range of possible physical strategies (Hill, $2011,2015)$. These can allow planners to assess current conditions and gain new insights about the spatial variability of vulnerability and change. For example, it is likely that logical pairings of urban district types with shoreline types will be needed, such as pairing floodable urban districts with wetland and beach/dune systems, rather than selecting a shoreline strategy independently. Typologies can also help to assess whether suitable strategies are being overlooked, perhaps unintentionally (Hill, 2015).

Finally, the use of an "adaptation conceptual framework" in urban environmental planning is prompting new uses of regional process models. Whether planners are using two-dimensional models of change in wetland response or sediment erosion, or more complex models of hydrodynamics and flooding (P. L. Barnard, Jaffe, \& Schoellhamer, 2013; Holleman \& Stacey, 2014), the change is in how the models are used. In a sustainability framework, the models would be used to optimize spatial configurations. In an adaptation framework, they are more likely to be used iteratively to gain successive approximations of what adaptations are likely to work well or cause problems. For example, the US Geological Survey has developed a hydrodynamic model of the San Francisco Bay that allows planners to estimate tidal flooding depths at different locations around the shoreline (P. Barnard, 2015). Early studies using similar models have shown that in some parts of the San Francisco Bay, building walls on shorelines as an adaptation mea- 
sure will increase the depth of flooding in nearby areas (Holleman \& Stacey, 2014). In only a few years, planners will be able to insert proposals for coastal adaptation into the model and predict whether those adaptation projects will make another property owner's situation worse. They could use that information to alter the design and re-test it, or to allow or deny a permit. As adaptation changes occur, they will have to be recorded in the physical descriptions within the model so that new predictions would continue to reflect current conditions.

\section{Changes in Philosophical Assumptions: Epistemology, Ontology, and Ethics in Environmental Planning}

One of the key assumptions that underlies urban environmental planning is an epistemological assumption that the processes and patterns of the past can serve as a guide to the future. We have been able to know what is "good" and therefore in need of conservation by comparing our present conditions to the conditions of the past (Steinitz, 2012). The past has been, in a philosophical sense, a source of authority for environmental planning (Spirn, 1984, 2002). We have treated the relatively new practices of industrial agriculture and urbanization as destabilizing forces which must be countered by planning. The goal was to retain and protect elements of an earlier landscape. Our assumption has been that biodiversity, ecosystems, air and water quality, and human health can all be protected most effectively if we retain the framework of a long-standing landscape mosaic (Forman, 1997; Forman \& Godron, 1986; Marsh, 1991).

In an effort to define and mimic a stable set of fundamental processes within urban regions, urban environmental planners have tended to represent the past as relatively stable. Yet studies from the 1960s demonstrated that American plants and animals experienced dramatic changes in range as a result of the last glaciation of North America, and that they returned individualistically to their current communities-not in the associations we have seen them occupy in over the last hundred years and more (Terasmae, 1970). In spite of that evidence, most environmental planners still tend to think and speak of these plant and animal communities as if they have been stable, and can be maintained as stable units of ecosystems. Given certain temporal scale assumptions, this was reasonable. But given current predictions for rapid climatic change, it is now necessary to let go of this epistemological assumption that the past should be our primary source of authority on how to prioritize the components of present and the future ecosystems (Davis \& Shaw, 2001). Presumably, it should be replaced with a heavier reliance on predictive models that represent the dynamics of systems, in spite of their uncertainties.

The second philosophical issue raised by global climate change is ontological, or related to how we conceptualize our larger world and its interactions. Scholars and planners have come to recognize that local regions are deeply affected by global trade and financial investment patterns (Harvey, 2000; Sassen, 2014), but nevertheless, professional planners are often put in the position of working as if their jurisdictions are coherent regions with development trajectories independent of global systems. This is an ontological assumption in the sense that policy makers and citizens may think the degree to which we live in a globalized system can be reduced, using new laws, policies and/or physical border walls (Porter, 2016). But in fact, we live in an unprecedented situation of simultaneous environmental and economic changes that continue to occur and produce cascading effects on a global scale.

A third philosophical issue involves the ethical assumptions that influence environmental planning. It has been accepted as reasonable in the United States for each generation to conserve some land from development, and pass this legacy on to future generations as a form of inter-generational inheritance; a legacy of natural resources that are represented by the proxy of geographic space (see for example, the dedication of a very large marine reserve by President Obama off the coastline of the US State of Hawai'i in September of 2016 [Hirschfeld Davis, 2016]). This act of reserving large areas of land has been the primary way in which American environmental planners fulfill their perceived obligations to future generations. For example, a renowned American biologist has recently called to set aside half of the earth to sustain biodiversity (Wilson, 2016). Other forms of contemporary resource use, such as fossil fuel use, have received less attention in an inter-generational context because the assumption is that technology will change and allow future humans to use other energy sources (Nicholson, 2015).

But climate change is forcing new, uncomfortable reflections on the scale and cost burden of the structural adaptation projects current generations should assume (Moellendorf, 2009; Moellendorf \& Schaffer, 2016). Should the generations that enjoyed the use of fossil fuels invest more of their resources to prepare for the future dynamics of flooding, drought, and fire that are the consequences of their unrestricted use of carbonbased fuels? In other words, should we build big adaptation projects now, before the seas rise much more rapidly, or should we defer that cost to future generations who will do it when it is needed (Grasso, 2010)?

Most planners, scientists and geographers who reflect on the onset of an Anthropocene era focus on defining the threshold at which that new era has begun or will begin (Braje, 2016; Waters et al., 2016). But from an ethical reasoning perspective, we could also interpret our current era as the last few stable decades of an 8,00010,000 year period (the Holocene). What is an ethically appropriate use of the last few decades of a long, stable period? Should we continue to optimize our investments to a lowest-cost, least-disruption adaptation pathway in the near future (Reeder \& Ranger, 2011) or are 
we ethically bound to do all we can for future generations, given that they will bear most of the costs of our past use of cheap fossil fuels (Grasso, 2010)? Seen in that light, the transition to the Anthropocene creates an urgent need to re-evaluate the goals of urban environmental planning projects, even if the effects of trends such as sea level rise may not be acute until after 2050. As a result, a wide range of new ethical questions are starting to be asked during discussions of appropriate goals and methods of planning for the Anthropocene (Graham \& Roelvink, 2010).

In summary, my argument in this section has been that three key philosophical assumptions are changing that underlie urban environmental planning: the epistemological assumption that the past is the key to knowledge about the future, the ontological assumption that regions can choose to become more independent from global systems; and the ethical assumption that we can defer the costs of urban adaptation to a changed climate to future generations.

\section{Conclusions}

The examples presented here provide evidence that pressures are mounting to drive a genuine shift in the concepts, methods and underlying assumptions of urban environmental planning in the United States, and more broadly in North America. Table 1 summarizes the examples presented under each category of praxis. This summary demonstrates that a series of changes have occurred in the concepts and goals of environmental planning over the last 30 years. My argument is that it is the

Table 1. Summary of a paradigm shift: how is our encounter with climate change beginning to change planning?

A Paradigm Shift involves changes to:

Epistemology-How do we know what sources of knowledge will be sufficient, given our uncertainty about the magnitude and complexity of future change? We are coping with the loss of the past as a guide to what is good or sufficient.

Ontology-How can we conceive of our new inter-scalar relationships? What is

Philosophical Assumptions local and global, when simultaneous changes in global processes are expressed locally, and local changes impact regional dynamics? We need to re-define the dependence/independence of local and regional choices, in both environmental and economic contexts.

Ethics-How much should we do now, and for whom/where?

Suitability-Goal was to put things in the right place, given long-term historical conditions.

Sustainability-Goal was to keep what we have, while mitigating/reducing carbon emissions.

Goals/Conceptual Frameworks

Resilience-Goal is to recover more quickly and with fewer losses after disaster events.

Adaptation - If we can't sustain some things in a new world ("native" species example), then the new goal is to accept new forms for cities and new characteristics of ecosystems that are adapted to new conditions, that are resilient to extreme events, and that reduce carbon emissions.

Vulnerability Assessments-Problematic to determine how to do this, when there are so many inter-related variables and processes, many changing simultaneously (uncertainties and scale interactions). Also problematic to do them in a way that defines/identifies particularly vulnerable communities, in an unequal social context (ethics).

End of Stationarity-We can no longer rely on statistical methods of the past. We need new ways of estimating sufficiency in plans, particularly regarding acceptable levels of risk.

Methods

Early Warning-We need to anticipate regime shifts. New statistical methods and interpretations seem to be emerging but are still unreliable.

Building Urban Districts-We can't use traditional types in traditional locations, and markets seem unlikely to supply the solution quickly. Typological approaches to search "solution spaces" may be most useful now.

Managing Complex Models-Regulators need to model and predict new regional dynamics, not just rely on patterns of the past. For coastal areas, new methods are available for quantitative regional models to support the regulatory process, but using them will also change that regulatory process. 
rapid turnover from sustainability to resilience to adaptation during the last 25 years, coupled with changes in methods and philosophical assumptions, which provides the evidence for a genuine paradigm shift.

Perhaps the greatest change as a result of climate trends is occurring in the rationale for urban environmental planning itself. The need to make strategic plans immediately to guide the interactions of communities with their environments -in the context of ethical arguments, contested financial investments, and predicted environmental changes -is more urgent than ever. If we accept the scientific evidence that we are currently enjoying the last stable decades of an 8,000-10,000 year period, 20-30 years from now we can expect to be in a state of perpetually responding to extreme conditions. Urban environmental planning has never been more urgently needed as a strategic planning approach, anticipating future change, rather than as a rear-guard effort to protect resources from development. We urgently need to expand and strengthen the concepts, methods and assumptions of urban environmental planning to incorporate predictions of rapid, permanent environmental change and prepare cities for the immediate future.

\section{Acknowledgements}

Over the last thirty years, I have had the opportunity to observe what is changing in environmental planning through the eyes of the professors and practitioners who taught me, my own public agency clients, academic and professional colleagues, and my students. Without them I would have very little perspective to contribute to a conversation about change. In particular, I would like to thank Carl Steinitz, Richard T. T. Forman, Sam Bass Warner, Jr., Anne Whiston Spirn, and Elizabeth K. Meyer for the sustained conversations we have had about change in American urban environments, all of which influenced the ideas in this review. In addition, an earlier draft of this manuscript was greatly improved by the comments of three anonymous reviewers.

\section{Conflict of Interests}

The author declares no conflict of interests.

\section{References}

Baker, L., Dove, M., Graef, D., Keleman, A., Kneas, D., Osterhoudt, S., \& Stoike, J. (2013). Whose diversity counts? The politics and paradoxes of modern diversity. Sustainability, 5(6), 2495-2518. doi:10.3390/ su5062495

Barnard, P. (2015). CoSMoS: Coastal storm modeling system. Reston. VA: United States Geological Survey. Retrieved from https://walrus.wr.usgs.gov/coastal_ processes/cosmos/

Barnard, P. L., Jaffe, B. E., \& Schoellhamer, D. H. (2013). Preface for special issue of Marine Geology.
Marine Geology, 345, 1-2. doi:10.1016/j.margeo. 2013.09.010

Beatley, T. (2000). Preserving biodiversity: Challenges for planners. APA Journal, 66(1), 4-20.

Berke, P., Newman, G., Lee, J., Combs, T., Kolosna, C., \& Salvesen, D. (2015). Evaluation of networks of plans and vulnerability to hazards and climate change: A resilience scorecard. Journal of the American Planning Association, 81(4), 287-302. doi:10.1080/ 01944363.2015 .1093954

Biging, G., Radke, J., \& Lee, J. H. (2012). Impacts of predicted sea level rise and extreme storm events on the transportaiton infrastructure in the San Francisco Bay region (No. CEC-500-2012-040). Sacramento, CA: California Energy Commission.

Bixler, R. P., Johnson, S., Emerson, K., Nabatchi, T., Reuling, M., Curtin, C., .. . Grove, J. M. (2016). Networks and landscapes: A framework for setting goals and evaluating performance at the large landscape scale. Frontiers in Ecology and the Environment, 14(3), 145153. doi:10.1002/fee. 1250

Boon, J. D., \& Mitchell, M. (2015). Nonlinear change in sea level observed at North American tide stations. Journal of Coastal Research, 316, 1295-1305. doi:10.2112/JCOASTRES-D-15-00041.1

Botzen, W. W., Michel-Kerjan, E., Kunreuther, H., de Moel, H., \& Aerts, J. C. (2016). Political affiliation affects adaptation to climate risks: Evidence from New York City. Climatic Change, 138(1), 353-360. doi:10.1007/s10584-016-1735-9

Braje, T. J. (2016). Evaluating the Anthropocene: Is there something useful about a geological epoch of humans? Antiquity, 90(350), 504-512. doi:10.15184/ aqy. 2016.32

California Coastal Commission. (2015). California Coastal Commission sea level rise policy guidance: Interpretive guidelines for addressing sea level rise in local coastal programs and coastal development permits. San Francisco, CA: California Coastal Commission. Retrieved from http://documents.coastal.ca.gov/as sets/sIr/guidance/August2015/0_Full_Adopted_Sea _Level_Rise_Policy_Guidance.pdf

Chelleri, L., Waters, J. J., Olazabal, M., \& Minucci, G. (2015). Resilience trade-offs: Addressing multiple scales and temporal aspects of urban resilience. Environment and Urbanization, 27(1), 181-198. doi:10.1177/0956247814550780

Coaffee, J., \& Lee, P. (2016). Urban resilience: Planning for risk, crisis and uncertainty. New York: Palgrave Macmillan.

Craig, R. K. (2005). Urban runoff and ocean water quality in Southern California: What tools does the clean water act provide. Chap. L. Rev., 9, 313.

Cutter, S. L., Boruff, B. J., \& Shirley, W. L. (2003). Social vulnerability to environmental hazards. Social Science Quarterly, 84(2), 242-261.

Dakos, V., Carpenter, S. R., van Nes, E. H., \& Scheffer, M. (2014). Resilience indicators: Prospects and lim- 
itations for early warnings of regime shifts. Philosophical Transactions of the Royal Society B: Biological Sciences, 370(1659), 20130263-20130263. doi:10.1098/rstb.2013.0263

Davis, M. B., \& Shaw, R. G. (2001). Range shifts and adaptive responses to quaternary climate change. Science, 292(5517), 673-679.

DeConto, R. M., \& Pollard, D. (2016). Contribution of Antarctica to past and future sea-level rise. Nature, 531(7596), 591-597. doi:10.1038/nature17145

DeFries, R., \& Malone, T. (1989). Global change and our common future: Papers from a forum. Washington, DC: Committee on Global Change, National Research Council, National Academy Press.

Feist, B. E., Buhle, E. R., Arnold, P., Davis, J. W., \& Scholz, N. L. (2011). Landscape ecotoxicology of coho salmon spawner mortality in urban streams. PLoS One, 6(8), e23424. doi:10.1371/journal.pone.0023424

Forman, R. T. T. (1997). Land mosaics: The ecology of landscapes and regions. Cambridge, UK: Cambridge University Press.

Forman, R. T. T., \& Godron, M. (1986). Landscape ecology. New York: Wiley.

Füssel, H.-M., \& Klein, R. J. T. (2006). Climate change vulnerability assessments: An evolution of conceptual thinking. Climatic Change, 75(3), 301-329. doi:10.1007/s10584-006-0329-3

Glibert, P. M., Icarus Allen, J., Artioli, Y., Beusen, A., Bouwman, L., Harle, J., . . . Holt, J. (2014). Vulnerability of coastal ecosystems to changes in harmful algal bloom distribution in response to climate change: Projections based on model analysis. Global Change Biology, 20(12), 3845-3858. doi:10.1111/gcb.12662

Goodenough, A. E. (2010). Are the ecological impacts of alien species misrepresented? A review of the "native good, alien bad" philosophy. Community Ecology, 11(1), 13-21.

Graham, J. K. G., \& Roelvink, G. (2010). An economic ethics for the Anthropocene. Antipode, 41, 320-346. doi:10.1111/j.1467-8330.2009.00728.x

Grasso, M. (2010). Justice in funding adaptation under the international climate change regime. Berlin: Springer.

Hannaford, J. (2015). Climate-driven changes in UK river flows: A review of the evidence. Progress in Physical Geography, 39(1), 29-48. doi:10.1177/ 0309133314536755

Harvey, D. (2000). Spaces of hope. Berkeley, CA: University of California Press.

Hill, K. (2011). Climate-resilient urban waterfronts. In J. Aerts, W. Botzen, M. Bowman, P. Dircke, \& P. Ward (Eds.), Climate adaptation and flood risk in coastal cities (pp. 123-144). Abingdon, Oxon: Routledge.

Hill, K. (2015). Coastal infrastructure: A typology for the next century of adaptation to sea-level rise. Frontiers in Ecology and the Environment, 13(9), 468-476. doi:10.1890/150088

Hills, G. A. (1974). A philosophical approach to landscape planning. Landscape Planning, 1, 339-371.

Hirschfeld Davis, J. (2016, August 26). Obama to create World's largest marine reserve off Hawaii. The New York Times. Retrieved from http://www.nytimes.com /2016/08/26/us/politics/obamas-action-will-createlargest-marine-reserve-on-earth.html

Hobbs, R. J., Higgs, E., Hall, C. M., Bridgewater, P., Chapin, F. S., Ellis, E. C., . . Y Yung, L. (2014). Managing the whole landscape: Historical, hybrid, and novel ecosystems. Frontiers in Ecology and the Environment, 12(10), 557-564. doi:10.1890/130300

Hodson, M., \& Marvin, S. (2009). "Urban ecological security": A new urban paradigm? International Journal of Urban and Regional Research, 33(1), 193-215. doi:10.1111/j.1468-2427.2009.00832.x

Holleman, R. C., \& Stacey, M. T. (2014). Coupling of sea level rise, tidal amplification, and inundation. Journal of Physical Oceanography, 44(5), 1439-1455. doi:10.1175/JPO-D-13-0214.1

Huler, S. (2012, June 12). Et tu, Virginia? Again with the sea level rise. Scientific American. Retrieved from https://blogs.scientificamerican.com/plugged-in/ettu-virginia-again-with-the-sea-level-rise

Hurricane Sandy Rebuilding Task Force. (2013). Rebuild by design: Hurricane Sandy regional planning and design competition design brief. Washington, DC: US Department of Housing and Urban Development. Retrieved from http://portal.hud.gov/hudportal/doc uments/huddoc?id=REBUILDBYDESIGNBrief.pdf

Jabareen, Y. (2015). The risk city: Cities countering climate change. Dordrecht, The Netherlands: Springer Netherlands.

Kelley, C. P., Mohtadi, S., Cane, M. A., Seager, R., \& Kushnir, Y. (2015). Climate change in the Fertile Crescent and implications of the recent Syrian drought. Proceedings of the National Academy of Sciences, 112(11), 3241-3246. doi:10.1073/pnas.1421533112

Kerans, B. L., \& Karr, J. R. (1994). A benthic index of biotic integrity (B-IBI) for rivers of the Tennessee Valley. Ecological Applications, 4(4), 768-785. doi:10.2307/1942007

King, J. (2009, July 15). Designers answer call to fight rising seas. San Francisco Chronicle.

Landphair, J. (2007). "The forgotten people of New Orleans": Community, vulnerability, and the Lower Ninth Ward. The Journal of American History, 94(3), 837-845.

Marin County Community Development Agency. (2015). Marin ocean coast sea level rise vulnerability assessment. San Rafael, CA: Marin County Community Development Agency .

Marsh, W. (1991). Landscape planning: Environmental applications. New York: Wiley.

McHarg, I. (1969). Design with Nature (1st ed.). Garden City, NY: Natural History Press.

McHarg, I. (1971). Man, planetary disease. Vital Speeches of the Day, 37(20), 634-731.

Milly, P. C. D., Betancourt, J., Falkenmark, M., Hirsch, 
R. M., Kundzewicz, Z. W., Lettenmaier, D. P., . . . Krysanova, V. (2015). On critiques of "Stationarity is dead: Whither water management?" Water Resources Research, 51(9), 7785-7789. doi:10.1002/ 2015WR017408

Milly, P. C. D., Betancourt, J., Falkenmark, M., Hirsch, R. M., Kundzewicz, Z. W., Lettenmaier, D. P., \& Stouffer, R. J. (2008). Stationarity is dead: Whither water management? Science, 319(5863), 573-574.

Moellendorf, D. (2009). Justice and the assignment of the intergenerational costs of climate change. Journal of Social Philosophy, 40(2), 204-224.

Moellendorf, D., \& Schaffer, A. (2016). Equalizing the intergenerational burdens of climate change-An alternative to discounted utilitarianism. Midwest Studies In Philosophy, 40(1), 43-62.

National Oceanic and Atmospheric Administration. (1999). Endangered and threatened species: Threatened status for three chinook salmon evolutionarily significant units (ESUs) in Washington and Oregon. Federal Register, 64(56), 14308-14328.

Nicholson, S. (2015). The birth of free-market environmentalism. Journal of Interdisciplinary History, 46(3), 421-433. doi:10.1162/JINH_a_00870

Otterstrom, S. M. (2004). A geographical history of United States city-systems: From the frontier to the urban transformation. Lewiston, NY: Edwin Mellen Press.

Pace, M. L., Carpenter, S. R., \& Cole, J. J. (2015). With and without warning: Managing ecosystems in a changing world. Frontiers in Ecology and the Environment, 13(9), 460-467. doi:10.1890/150003

Palmer, M. A., \& Ruhl, J. (2015). Aligning restoration science and the law to sustain ecological infrastructure for the future. Frontiers in Ecology and the Environment, 13(9), 512-519. doi:10.1890/150053

Porter, E. (2016, September 6). The crumbling case for a Mexican border wall. The New York Times. Retrieved from http://www.nytimes.com/ 2016/09/07/business/economy/the-crumbling-casefor-a-mexican-border-wall.html

Rapport, D. J., Gaudet, C., Karr, J. R., Baron, J. S., Bohlen, C., Jackson, W., ... Pollock, M. M. (1998). Evaluating landscape health: Integrating societal goals and biophysical process. Journal of Environmental Management, 53(1), 1-15.

Reeder, T., \& Ranger, N. (2011). How do you adapt in an uncertain world? Lessons from the Thames estuary 2100 project (World Resources Report Uncertainty Series). Washington, DC: World Resources Institute. Retrieved from www.worldresourcesreport.org

Rockström, J., Falkenmark, M., Allan, T., Folke, C., Gordon, L., Jägerskog, A., . . . Varis, O. (2014). The unfolding water drama in the Anthropocene: Towards a resilience based perspective on water for global sustainability. Ecohydrology, 7(5), 1249-1261. doi:10.1002/eco.1562

Sassen, S. (2014). Expulsions: Brutality and complexity in the global economy. Cambridge, MA: The Belknap Press of Harvard University Press.

Scheffer, M., Carpenter, S. R., Lenton, T. M., Bascompte, J., Brock, W., Dakos, V., . . Vandermeer, J. (2012). Anticipating critical transitions. Science, 338(6105), 344-348. doi:10.1126/science.1225244

Shi, L., Chu, E., \& Debats, J. (2015). Explaining progress in climate adaptation planning across 156 U.S. municipalities. Journal of the American Planning Association, 81(3), 191-202. doi:10.1080/01944363.2015. 1074526

Simenstad, C., Tanner, C., Crandell, C., White, J., \& Cordell, J. (2005). Challenges of habitat restoration in a heavily urbanized estuary: Evaluating the investment. Journal of Coastal Research, SI(40), 6-23.

Sorte, C. J. B. (2013). Predicting persistence in a changing climate: Flow direction and limitations to redistribution. Oikos, 122(2), 161-170. doi:10.1111/j.16000706.2012.00066.x

Spirn, A. (1984). The granite garden: Urban nature and human design. New York: Basic Books.

Spirn, A. (2002). The authority of Nature: Conflict, confusion, and renewal in design, planning, and ecology. in ecology and design: Frameworks for learning. Washington, DC: Island Press.

Stedinger, J. R., \& Griffis, V. W. (2011). Getting from here to where? Flood frequency analysis and climate. Journal of the American Water Resources Association, 47(3), 506-513. doi:10.1111/j.1752-1688. 2011.00545.x

Steinitz, C. (1990). A framework for theory applicable to the education of landscape architects (and other environmental design professionals). Landscape Journal, 9(2), 136-143.

Steinitz, C. (2012). A framework for GeoDesign: Changing geography by design. Redlands, CA: ESRI.

Stone, B. (2012). The city and the coming climate: Climate change in the places we live. Cambridge, UK: Cambridge University Press.

Stroup, L. J. (2011). Adaptation of US water management to climate and environmental change. The Professional Geographer, 63(4), 414-428.

Terasmae, J. (1970). Quaternary Palynology: Its scope, problems and potential uses. Proceedings of the Annual Meeting. American Association of Stratigraphic Palynologists, 1, 23. doi:10.2307/3687299

Thomas, C. (2003). Bureaucratic landscapes: Interagency cooperation and the preservation of biodiversity. Cambridge, MA: MIT Press. (Original work published 1997)

Verschuuren, J. (2004). Effectiveness of nature protection legislation in the European Union and the United States: the habitats directive and the endangered species act. In M. Dieterich \& J. Van Der Straaten (Eds.), Cultural landscapes and land use (pp. 39-67). Springer. Retrieved from http://link.springer.com/ content/pdf/10.1007/1-4020-2105-4_4.pdf

Waggonner and Ball Architects. (2013). Greater New 
Orleans water management plan. New Orleans, LA: GNO, Inc. Retrieved from www.livingwithwater.com

Waggonner, D., \& Meyer, H. (2010). Dutch Dialogue 2. Retrieved from http://dutchdialogues.com/2010/05/ 03/dutch-dialogue-2/

Wang, F., Tang, Q., \& Wang, L. (2014). Post-Katrina population loss and uneven recovery in New Orleans, 2000-2010. Geographical Review, 104(3), 310-327.

Ward, E. J., Anderson, J. H., Beechie, T. J., Pess, G. R., \& Ford, M. J. (2015). Increasing hydrologic variability threatens depleted anadromous fish populations. Global Change Biology, 21(7), 2500-2509. doi:10.1111/gcb.12847

Waters, C. N., Zalasiewicz, J., Summerhayes, C., Barnosky, A. D., Poirier, C., Gałuszka, A., ... Wolfe, A. P. (2016).
The Anthropocene is functionally and stratigraphically distinct from the Holocene. Science, 351(6269). doi:10.1126/science.aad2622

Weisz, C., Blumberg, A. F., \& Keenan, J. M. (2015). Design meets science in a changing climate: A case for regional thinking to address urban coastal resilience. Social Research: An International Quarterly, 82(3), 839-857.

Wheeler, S., \& Beatley, T. (2014). Sustainable development reader. New York: Routledge.

Wilson, E. O. (2016). Half Earth: Our planet's fight for life. New York: W. W. Norton.

World Commission on Environment and Development. (1987). Our common future. Oxford, UK: Oxford University Press.

\section{About the Author}

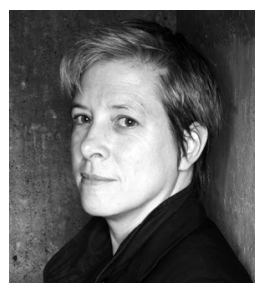

Kristina Hill is a researcher and environmental planner who develops adaptation strategies for sea level rise. She helped to develop a new water strategy for New Orleans in 2013, and recently edited the $100^{\text {th }}$ anniversary issue of the Ecological Society of America's journal, Frontiers, on the topic of infrastructure for adaptation to climate change. She received her PhD from Harvard University, and is an associate professor at UC Berkeley in landscape architecture and environmental planning. 